\title{
Materials Design for Improving Teachers' Pedagogical Competence: What and How Effective
}

\author{
Siti Tarwiyah $^{1}$, Joko Priyana ${ }^{2}$, Lulut Widyaningrum ${ }^{3}$ \\ Universitas Islam Negeri Walisongo, Jl. Prof. Dr. Hamka Ngaliyan Semarang ${ }^{1,3}$ \\ Universitas Negeri Yogyakarta, Jl. Colombo Yogyakarta No.1, Karang Malang, Caturtunggal, \\ Kec. Depok, Kabupaten Sleman, Daerah Istimewa Yogyakarta 55281² \\ \{siti_tarwiyah@walisongo.ac.id ${ }^{1}$,joko.priyana@uny.ac.id², lulut.widyaningrum@walisongo.ac.id ${ }^{3}$ \}
}

\begin{abstract}
Materials development plays a pivotal role in a coaching program. It needs to be prevented from coach-centred material development. This paper describes coachee-involving materials development in a coaching program for EFL teachers in the context of Indonesian Curriculum and its effectiveness in improving the teachers' pedagogical competence. Data were collected through observation, Focus Group Discussion with 6 EFL Junior High School teachers and documentation. The data were analysed through interactive model and Wilcoxon Signed Rank Test. Findings exposed that instructional designs dealing with teaching four language skills, vocabulary, and grammar are primarily needed by the teachers. The materials are effective in improving the teachers' teaching practices, which is reflected in the influence of the improvement of the teachers' pedagogical competence on the enhancement of the students' outcomes. This study contributes to the literature of teacher professional development on some considerations underlying the design of materials for enhancing teachers' pedagogical competence.
\end{abstract}

Keywords: Materials Development; Pedagogical Competence; Teacher Professional Development

\section{Introduction}

It is believed that personal, pedagogical, intellectual/professional, and social capacity supports teachers in conducting their teaching. Teachers, in this case, organize the content, process, facility, and assessment standard to reach graduate competence standard. Regarding this fact, professional growth is demanded. The more professional a teacher is, the more qualified the output of a certain education institution will be.

Materials development becomes a crucial thing in a professional development practice, since it is a determinant matter to reach the goal of the practice. Hence, determining materials based on participants' need is demanded. [1] discussed factors affecting materials development of a teacher training. [2] developed a model of historical instructional material representing local history-based teaching materials. The materials are purposed to facilitate the teaching of local historical events. [3] proved that materials comprising basic knowledge in EFL and teaching methodology, material development; evaluating text book, preparing 
materials, on-service activities, i.e. peer, micro teaching, critical tasks, i.e. analyzing, comparing, problem-solving are effectively designed for an In House Training (IHT) aimed at improving the teachers' ability in developing teaching-learning materials. [4] proved the effectiveness of materials designed for learning and teaching course. The products had been qualitatively validated in terms of content, language, and design. [5] proved the effectiveness of materials developed for teacher training. [6] studied choice in EAP materials development.

Materials development becomes the key factor in the achievement of the objective of a teaching or professional development program. The previous studies proved its importance. Meanwhile, few studies have been done on the involvement of professional development participants in materials development, which makes it the basic issue in research. This study focuses on describing materials used in a coaching program, which was designed by involving the coaching participants and prove its effectiveness in improving the teachers' pedagogical competence by identifying the influence of the enhancement of the teachers' pedagogical competence on the students' outcomes.

\section{Literature Review}

\subsection{Materials Development in Teacher Professional Development}

Developing materials is a part of teachers' pedagogical competence. Regarding material development, [7] assert there is no specific 'theory' of developing materials. They are developed by considering the ways learners learn. Materials development determines the quality of teacher training or student learning, which then contributes to what so called rich education. [8] Mentions 3 components of rich education, i.e. (1) educators or policymakers who make sure the completeness of instructional program, (2) the idea of placing human as capital in education by improving the quality of teachers through training programs, (3) assessment which is used to measure more complex tasks result from richer learning.

Rich education is implemented by professional teachers. Those who are familiar with professional development activities. There are 5 characteristics of highly qualified professional development in which materials and instructional designs become dominant characteristics (see 1, 2, 3); (1) aligned with the goals of school, the standards and assessments of state and district. There is also synergy between the activities of the program with other professional learning, (2) focuses on materials and instructional strategies, (3) involves teachers in the experimentation of new teaching strategies, (4) provides collaboration activities, employs continues feedbacks and follow-up [1].

To conclude, materials for teacher professional development are aimed at facilitating the teachers to develop their pedagogical and professional competence. The materials are exposed through methods, which give opportunity for the teachers to develop their social and interpersonal competence.

\subsection{Pedagogical Competence}

A pedagogically competent teacher can manage all the processes of learning, from planning, implementing, assessing and evaluating. Manageable learning facilitates students to reach learning goals. Tsui, cited in [9] differenciates a novice teacher and an expert teacher. An expert teacher is more knowledgable, better at intuitive judgement, desirous of teaching 
investigation, aware of instructional objectives and learning context, automatic in teaching, and sensitive to students and their learning.

[10] is among experts who explains about competent teachers. She uses the term good teachers instead of competent teachers. In her opinion, a good EFL teacher is characterized by ten characteristics, i.e. (1) his enthusiasm in teaching, (2) creativity, (3) pace and humor, (4) challenge, (5) being encouragement and patience, (6) attention to students' interest, (7) knowledge in grammar, (8) time provision for questions and answers, (9) equal treatment to students regardless of sex, marital status, race, or their future need for the language, and (10) emotional control.

Meanwhile, Indonesian Government Regulation No. 19 Year 2005 on National Education Standard Article 28 Sub-article 3 defines pedagogical competence as the competence to manage the learning of learners which covers understanding learners, planning and implementing a lesson, evaluating products of learning, and developing learners to actualize their potentials.

In addition, Williams, as cited in [11] mentions three competences of English teacher, i.e. (1) a very good knowledge of grammar, (2) phonetics and pronunciations, (3) vocabulary and usage. More specifically, the addendum of Minister of Education Decree No. 16/2007 on the standard of academic qualification and teacher competence mentions the cores of pedagogical competence as follows: (1) understanding students' characteristics from physical, moral, spiritual, social, cultural, emotional, and intellectual aspects, (2) mastering theories and principles of learning, (3) developing curriculum in relation to the taught subject, (4) conducting educating learning; (5) employing information and communication technology for the purpose of learning, (6) facilitating the development and the actualization of learners' potential, (7) communicating with learners effectively, emphatically, and politely, (8) conducting assessment and evaluation of the process and the product of learning, (9) making use of assessment and evaluation for learning purposes, and (10) doing reflective activities to improve the quality of learning.

[12] states that pedagogical competence of Language Teacher Educator (LTE) and Language Teacher (LT) is the competence in teaching language. The competence covers management, teaching, preparation, and assessment components. Management component is represented in the classroom management skills covering rapport establishment, equipment and material management. With the skills a teacher carries on a lesson smoothly. Teaching component relates to skills to handle communicative activities. Preparation component comprises identifying and organizing activities based on learning objectives. This component also considers strategies and resources. Preparation component involves management and teaching skills. Assessment component requires teacher to assess his teaching and management skills. It is a kind of reflection and evaluation of teaching.

Similar to the above opinion, [13] mentions that pedagogical competence ' $\ldots$ is concerned with classroom management, questioning techniques, lesson planning, teaching strategies, and the numerous daily tricks of the trade ...' as a professional teacher. To summarize, pedagogical competence is the competence of organizing teaching-learning process through planning, implementing, assessing and evaluating.

\section{Methodology}

This study is a case study using mixed methods. Case study tries to explain the procedure and the reasons a decision and decision making, its implementation and results [14]. The 
participants were 6 EFL Islamic Junior High School teachers. Documentation and observation were used to describe the teachers' room for improvement in teaching, what materials were still needed to improve their teaching. Documents of the teachers' lesson plans and the teachers' teaching performance implementing the plans were used as the data sources. Tentative materials were identified based on the results of documentation and observation. The temporarily formulated materials were, then, confirmed in a Focus Group Discussion (FGD).

The fixed materials were developed and organized along with the assessment instruments to measure the achievement of the goals of the exposure of each material. The organized materials were trained to the participants within 6 week-meeting. Their pedagogical competence was measured before and after the training using instruments which were validated through expert judgement, whose aim was identifying the teachers' pedagogical competence improvement. The enhancement of the students' outcomes were also measured. The results of both measurements were used to identify the influence of the improvement of the teachers' pedagogical competence on the enhancement of the students' outcomes, which reflected the effectiveness of the designed materials in improving the teachers' teaching plan and practices. The value of the influence was measured using Wilcoxon signed rank test.

\section{Findings and Discussion}

\subsection{Developing the Materials for Coaching Program}

\subsubsection{Assessing the Teachers' Needs}

Need analysis was conducted through observation of the teachers' teaching, studying the documents of the teachers' lesson plan, and FGD. The first two activities were aimed at identifying rooms for improvement, what materials are needed to be exposed in order to recover the weaknesses. Need analysis is an essential part of a program. It is influential on the success of the program design, implementation, evaluation and revision Richard, in [15]. Table 1 and 2 show the scores of instructional plan and practice of the six EFL teachers (Teachers 1-6). There are six aspects of instructional plan with the scores ranging from 1 to 10. The Score was given based on the degree of appropriateness of each aspect. For example, preparing materials as the second aspect of the teachers' instructional plan.

Table 1. The Score of Teachers' Instructional Plan

\begin{tabular}{lllllcccc}
\hline \multirow{2}{*}{ No. Aspect } & \multicolumn{1}{c}{ As } & $\mathbf{1}$ & $\mathbf{2}$ & $\mathbf{3}$ & $\mathbf{4}$ & $\mathbf{5}$ & $\mathbf{6}$ & $\sum$ \\
\cline { 2 - 8 } & Formulating objectives & 4 & 4 & 4 & 4 & 4 & 2 & 3.67 \\
2 & Preparing materials & 4 & 5 & 6 & 4 & 4 & 4 & 4.5 \\
3 & Determining methods & 4 & 5 & 4 & 6 & 4 & 3 & 4.3 \\
4 & Determining learning sources and media & 4 & 5 & 5 & 6 & 4 & 4 & 4.7 \\
5 & Designing assessment instruments & 5 & 6 & 4 & 5 & 4 & 4 & 4.7 \\
6 & Allocating time & 8 & 8 & 8 & 8 & 8 & 8 & 8 \\
\hline
\end{tabular}

Table 2. The Score of Teachers' Instructional Practice

\begin{tabular}{lrrrrrrrr}
\hline \multirow{2}{*}{ No. } & \multirow{2}{*}{ Aspect } & $\mathbf{1}$ & $\mathbf{2}$ & $\mathbf{3}$ & $\mathbf{4}$ & $\mathbf{5}$ & $\mathbf{6}$ & $\sum$ \\
\cline { 2 - 9 } & Opening a lesson & 4 & 7 & 6 & 7 & 4 & 4 & 5.3 \\
\hline 1
\end{tabular}




\begin{tabular}{llccccccc}
\hline \multirow{2}{*}{ No. Aspect } & \multicolumn{1}{c}{ Teacher } \\
\cline { 2 - 8 } & $\mathbf{1}$ & $\mathbf{2}$ & $\mathbf{3}$ & $\mathbf{4}$ & $\mathbf{5}$ & $\mathbf{6}$ & $\sum$ \\
\hline 2 & Delivering materials & 6 & 8 & 6 & 7 & 4 & 4 & 5.8 \\
3 & Using media and methods & 4 & 4 & 4 & 6 & 4 & 4 & 4 \\
4 & Using communicative language & 9 & 9 & 8 & 9 & 5 & 5 & 7.5 \\
5 & Motivating students & 7 & 8 & 7 & 8 & 6 & 6 & 7 \\
6 & Organizing activities efficiently & 5 & 6 & 6 & 6 & 4 & 4 & 5.2 \\
7 & Concluding a lesson & 7 & 8 & 8 & 8 & 7 & 6 & 7.3 \\
8 & Providing feedback & 7 & 9 & 9 & 9 & 7 & 6 & 7.8 \\
9 & Conducting assessment and evaluation & 5 & 6 & 6 & 6 & 4 & 4 & 5.2 \\
10 & Using time effectively & 8 & 10 & 10 & 9 & 7 & 7 & 8.5 \\
\hline
\end{tabular}

In planning stage, the teachers still have problems in formulating objectives, preparing materials, determining methods, learning sources and media, and designing assessment instruments. In implementing stage, the teachers mainly have problems in opening a lesson, delivering materials, using media and methods, organizing activities, and conducting assessment and evaluation.

FGD was important to uncover the problems of pedagogical competence, which were not identified through studying the teachers' lesson plans and observing their teaching performances. In the FGD, the teachers proposed the exposure of some language teaching strategies, which support the realization of activity-based learning. FGD was also conducted to make an agreement with the teachers of the school about the time, place, and procedures of coaching.

The data got from observing the teaching-learning processes, studying the teachers' lesson plan, and FGD also uncovered the following qualitative data:

a. The teachers' understanding of the implementation of 2013 Curriculum was limited.

b. The teachers had problems in designing activity-based learning. Consequently, they still played more as information sources than facilitators. Being an information source is considered more practical, designing activity-based learning is, in fact, more difficult and time consuming.

c. The teachers had problems in planning and conducting assessment; compossing lattice of instrument, instrument, and scoring rubric. Some instruments were linguistically and conceptually incorrect, instructions were still inappropriately given.

Those problems were identified as the teachers' needs. The teacher still had problems with accommodating $21^{\text {st }}$ century skills (critical thinking, collaboration, communication, creativity), which should have been represented through creating varied learning activities and conducting proper assessment.

\subsubsection{Developing Materials and Worksheet}

After identifying the teachers' needs through documentation, observation and FGD, materials were developed. It means that the materials were localized [6]. It was made appropriate with the needs of teachers at the school. The table below shows the materials presented and discussed from the first to the sixth meeting.

Table 3. List of Materials

\begin{tabular}{cl}
\hline Week & \multicolumn{1}{c}{ Material } \\
\hline 1 & Using Songs in EFL Class \\
& Learning Principles and Activity-Based Learning \\
\hline
\end{tabular}




\begin{tabular}{cl}
\hline Week & \multicolumn{1}{c}{ Material } \\
\hline 2 & $\begin{array}{l}\text { Learning Methods in the 2013 Curriculum } \\
\text { Teaching Vocabulary } \\
\text { Scientific Approach }\end{array}$ \\
3 & $\begin{array}{l}\text { Inquiry Learning } \\
\text { Teaching Grammar } \\
\text { Problem-Based Learning }\end{array}$ \\
& $\begin{array}{l}\text { Genre-Based Instruction } \\
\text { Teaching Listening and Speaking }\end{array}$ \\
5 & $\begin{array}{l}\text { Contextual Learning } \\
\text { Teaching Reading and Writing }\end{array}$ \\
6 & $\begin{array}{l}\text { Assessing Attitude, Knowledge, Skill } \\
\text { Process Skills (Planning, Implementing, Assessing and Evaluating a Lesson) }\end{array}$ \\
\hline
\end{tabular}

The materials were developed based on the teachers' needs. It is just like conducting a class session, where we employ diagnostic test first to identify students' need, which is continued with formulating objectives and developing materials. To support the material delivery some worksheets were used. Below is the example of worksheet used to expose the participants with Contextual Learning.

Coaching Worksheet

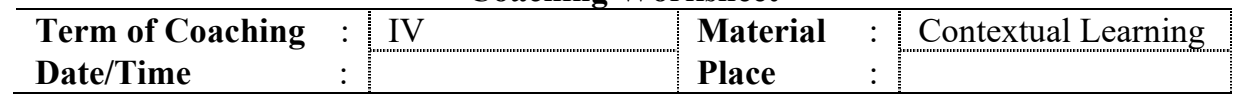

\section{The features of contextual learning}

- There is team work among students in the class.

- Emphasizing on problem solving

- Accommodating students' backgrounds

- Fun, not a boring teaching

- Integrated learning (theory, practice, skills)

- Making use of various sources

- Student engagement

- Student sharing

- Critical students and creative teacher

- Products of learning; pictures, articles, humour, etc.

\section{Questions:}

1. Find the activities in the video showing each features of contextual learning!

2. If you were the teacher of the students, what would you do differently?

Fig. 1. Sample of Coaching Worksheet

The exposure was done through the following steps: (1) presenting the features of Contextual Learning, (2) playing a video of learning and having the coachees identify which activity represents which feature and what they would do differently if they were the teacher, (3) eliciting different ideas of learning activities from the coachees (if they were the teachers in the video), (4) giving confirmation after sharing session

The process of developing materials used textbook adaptation strategy. The materials were taken from some sources and adapted in order to be appropriate with the teachers' need. Study conducted by [16] also proved that EFL instructors had positive belief in adaptation strategy in developing learning materials. 
To conclude, the beginning stage of a course design is assessing needs. After the needs are clearly identified, objectives are formulated and materials are developed. To ensure whether the objectives are reached, assessment is designed based on the characteristics of the materials. All materials and assessments are organized in a systematical order to facilitate the achievement of the objectives. The systematically organized materials and assessments are checked and completed to conceptualized course content.

\subsection{The Improvement of Teachers' Pedagogical Competence}

Pedagogical competence comprises planning, implementing, assessing and evaluating. Data of the teachers' planning competence comprise 8 aspects and 43 indicators. Each indicator was scored 10. The total score was $430: 43=10$. Meanwhile, data showing the teachers' implementing competence had 7 aspects and 36 indicators. The total score was 360 : $36=10$. Data exposing the teachers' assessing and evaluating competence contained 4 aspects and 17 indicators, with the total score $170: 17=10$. The score of the teachers' competence in planning, implementing, assessing, and evaluating an English lesson before and after being exposed with the developed materials falls into 5 categories, i.e. excellent $(8 \geq)$, good (7-8), fair (6-7), bad (5-6), and very bad $(\leq 5)$.

Overall, the designed materials enhances the teachers' competence in planning, implementing, assessing and evaluating an English lesson. The average score of the teachers' competence in planning an English lesson before and after the exposure improves 1.073 points from 5.646 (bad) to 6.719 (fair). The teachers' competence in implementing an English lesson strengthens to 7.129 (good), from 3.976 (very bad) or it improves 3.153 points. The teachers' competence in assessing and evaluating an English lesson also develops with 3.542 points improvement from 4.571 (bad) to 8.113 (excellent). The improvement is summarized in the following table.

Table 4. Score of the Teachers' Planning, Implementing, Assessing and Evaluating Competence before and after being Exposed with the Developed Materials

\begin{tabular}{|c|c|c|c|c|}
\hline Competence & Aspect & $\begin{array}{c}\text { Before } \\
\text { Coaching }\end{array}$ & $\begin{array}{c}\text { After } \\
\text { Coaching }\end{array}$ & Progress \\
\hline \multirow[t]{10}{*}{ Planning } & $\begin{array}{l}\text { Formulating Objectives and/or Indicators } \\
\text { Preparing Materials }\end{array}$ & 8.217 & 9.283 & 1.066 \\
\hline & Planning the Activities & 3.367 & 7.383 & 4.016 \\
\hline & Determining Learning Sources, Media & 8.100 & 9.583 & 1.483 \\
\hline & Designing Assessment and Evaluation & 4.450 & 7.533 & 3.083 \\
\hline & Instrument & 6.117 & 5.424 & -0.693 \\
\hline & Allocating Time & & & \\
\hline & Remedial and Enrichment Program & 6.333 & 5.333 & -1 \\
\hline & Overall Arrangement & .000 & 0.833 & 0.833 \\
\hline & & 8.583 & 8.833 & 0.25 \\
\hline & Mean & 5.646 & 6.719 & 1.073 \\
\hline \multirow[t]{8}{*}{ Implementing } & Opening a Lesson & 2.683 & 7.417 & 4.734 \\
\hline & Organizing the Activities & 6.050 & 8.850 & 2.800 \\
\hline & Using Media & 5.467 & 8.600 & 3.133 \\
\hline & Using Communicative Language & 5.313 & 5.771 & 0.458 \\
\hline & Motivating Student & 5.833 & 9.567 & 3.734 \\
\hline & Using Time Effectively & 4.167 & 9.333 & 5.166 \\
\hline & Closing a Lesson & 2.292 & 7.500 & 5.208 \\
\hline & Mean & 4.544 & 8.148 & 3.605 \\
\hline
\end{tabular}




\begin{tabular}{|c|c|c|c|c|}
\hline Competence & Aspect & $\begin{array}{c}\text { Before } \\
\text { Coaching }\end{array}$ & $\begin{array}{c}\text { After } \\
\text { Coaching }\end{array}$ & Progress \\
\hline \multirow[t]{2}{*}{ Assessing } & Assessing attitudes, knowledge, and skills & 3.017 & 4.667 & 1.650 \\
\hline & Classifying and processing the Result & 5.833 & 10.000 & 4.167 \\
\hline \multirow[t]{3}{*}{ Evaluating } & $\begin{array}{l}\text { Making interpretation, determining the } \\
\text { correlated problems }\end{array}$ & 6.667 & 10.000 & 3.333 \\
\hline & Identifying the needs for follow up & 2.767 & 7.783 & 5.016 \\
\hline & Mean & 4.571 & 8.113 & 3.542 \\
\hline
\end{tabular}

Those results prove the success of the materials exposure, which were developed by considering the teachers' needs, based on careful observation, document study, and FGD. The score represents the changes in classroom practices of the teachers. [17] states that a professional development program is "a systematic and concerted effort to bring about innovation and changes in classroom practices of teachers, their attitudes and beliefs, and learning outcomes of students".

\subsection{The Ways the Teachers' Pedagogical Competence Influences the Students' Outcomes}

The improvement of the teachers' pedagogical competence influences the students' outcomes. It is seen based on the data analysis using Wilcoxon Signed Rank Test, through the result in which $\mathrm{p}$-value $<$ alpha $=5 \%$. The calculation proves that all components of pedagogical competence influences the students' outcomes. This is a concrete impact of the enhancement of the teachers' pedagogical competence after being exposed with the materials which were carefully designed. It means that the materials designed for the coaching program is meaningful for recovering the weaknesses of the teachers' pedagogical competence. [17] states that professional development covers processes and activities in improving the students' learning through the enhancement of the teachers' knowledge, skills, and attitudes.

The biggest influence on the students' outcome is from assessing and evaluating competence with p-value 0.046. It is, then, followed by implementing and planning competence respectively with p-value 0.28 and 0.27 . Below are the results showing that influence.

Table 5. P-Value of the Influence of Teachers' Competence on Students' Outcome

\begin{tabular}{|l|r|r|r|}
\hline & $\begin{array}{c}\text { Planning } \\
\text { Competence }\end{array}$ & $\begin{array}{c}\text { Implementing } \\
\text { Competence }\end{array}$ & $\begin{array}{r}\text { Assessing and Evaluating } \\
\text { Competence }\end{array}$ \\
\hline$Z$ & $-2.207^{\mathrm{b}}$ & $-2.201^{\mathrm{b}}$ & $-1.992^{\mathrm{b}}$ \\
& 0.027 & 0.028 & 0.046 \\
\hline
\end{tabular}

To explain more about the influence of the improvement of the teachers' assessing and evaluating competence on the students' outcomes, let us focus on data in table 6 . The data show that the biggest improvement of assessing and evaluating competence is found in the aspect of identifying the need for follow up with the score 5.016. The indicators of this aspect are conducting remedial and enrichment program, identifying rooms for improvement for teaching the same materials in the future, and setting up policies for teaching the next class. The following aspect is classifying and processing result (4.167 points) in which the teacher classified the scores to map the students' classification and reported the scores to the students. 
The third aspect is making interpretation and determining the correlated problems, with 3.333 points. The teachers interpreted the score classification to identify the need for enrichment and remedial programs. The indicator with the least point of improvement is assessing attitudes, knowledge, and skills (1.650 points). This aspect covers 11 indicators. Of the eleven indicators, using HOTs question to assess students' knowledge is the indicator which was seldom implemented by the teachers.

Table 6. Score of the Teachers' Assessing and Evaluating Competence before and after being Exposed with the Developed Materials

\begin{tabular}{llccc}
\hline \multirow{2}{*}{ Competence } & \multicolumn{1}{c}{ Aspect } & $\begin{array}{c}\text { Before } \\
\text { Coaching }\end{array}$ & $\begin{array}{c}\text { After } \\
\text { Coaching }\end{array}$ & Enhancement \\
\hline Assessing & $\begin{array}{l}\text { Assessing Attitudes, Knowledge, and Skills } \\
\text { Classifying and processing the Result }\end{array}$ & 3.017 & 4.667 & 1.650 \\
& & 5.833 & 10.000 & 4.167 \\
Evaluating & $\begin{array}{l}\text { Making Interpretation, determining the } \\
\text { correlated Problems }\end{array}$ & 6.667 & 10.000 & 3.333 \\
& Identifying the Needs for Follow up & 2.767 & 7.783 & 5.016 \\
Mean & & 4.571 & 8.113 & 3.542 \\
\hline
\end{tabular}

As assessing and evaluating competence made the biggest improvement, consequently the teachers became more reflective. As the teachers became more reflective, they planned, implemented, assessed and evaluated their coming lessons more carefully after learning from the previous experiences. A better planned learning results in better students' outcomes. "Reflective teaching goes hand-in-hand with critical self-examination and reflection as a basis for decision making, planning, and action" [9]. The enhancement of the teachers' assessing and evaluating competence also imply the teachers' consequence to conduct remedial and enrichment program, identify rooms for improvement for teaching the same materials in the future, and set up the policies of the next class teaching. With those consequences there must be additional learning and services to the remedial learners, better planned and improved next teaching after making deep teaching reflection by identifying rooms for improvement. Reflection gives teachers opportunity to look at themselves and the world differently [18].

\section{Conclusions}

Designing materials for teacher professional development is mainly aimed at enhancing the teachers' pedagogical and professional competence. Carefully designed materials help the teachers improve the competence. This study proves that effectively developed materials based on the teachers' needs for improving their pedagogical competence brings the meaningful impact on the enhancement of the teachers' pedagogical competence, which then gives positive influence on the students' outcomes. The average score of the teachers' competence in planning an English lesson before and after being exposed with the developed materials improves 1.073 points from 5.646 (bad) to 6.719 (fair). The teachers' competence in implementing an English lesson strengthens to 7.129 (good), from 3.976 (very bad) or it improves 3.153 points. The teachers' competence in assessing and evaluating an English lesson also develops with 3.542 points improvement from 4.571 (bad) to 8.113 (excellent). The improvement of the teachers' pedagogical competence gives positive influence on the students' outcomes. The biggest influence is from assessing and evaluating competence with p-value 0.046 . It is, then, followed by implementing and planning competence respectively with p-value 0.28 and 0.27 . The result suggests that materials have participant impact [19]. 


\section{Reference}

[1] S. Archibald, J. G. Coggshall, A. Croft, and L. Goe, "High-Quality Professional Development for All Teachers: Effectively Allocating Resources," Natl. Compr. Cent. Teach. Qual., p. 32, 2011.

[2] Djono, "The Development of Historical Instruction / Teaching Material in Senior High Schools Based on Local History with SOI Approach DIJE. Vol 1," vol. 1, 2013.

[3] N. Sri Lengkanawati, S. Setyarini, R. Della Kartika Sari, and N. Y. Moecharam, "In house training (IHT) model to improve the abilities of English teachers in developing teaching materials," Indones. J. Appl. Linguist., vol. 5, no. 1, pp. 36-42, 2015.

[4] F. A. Nai, I. N. S. Degeng, P. Setyosari, and U. Widiati, "Teaching Material Development 0f Learning and Teaching Course Through Lesson Study Application for University Students,” Educ. 21th Century Responding to Curr. Issues, pp. 273-283, 2016.

[5] K. T. Sipayung and T. Pangaribuan, "Developing Teaching Materials on English for Specific Purpose on Tourism Program of HKBP Grade Eleven," Asian EFL J., vol. 23, no. 63, pp. 94-106, 2019.

[6] L. Kohnke, "Exploring critical pedagogy and choice in eap material development: A case study," J. Asia TEFL, vol. 16, no. 4, pp. 1219-1231, 2019.

[7] F. Mishan and I. Timmis, "Materials development for TESOL," Mater. Dev. TESOL, pp. 1-218, 2015.

[8] A. J. Rotherham and D. Willingham, "21st Century Skills: The Challenges Ahead What Will It Take ?," Educ. Leadersh., vol. 67, no. 1, pp. 16-21, 2009.

[9] J. C. Richards and C. Lockhart, Reflective Teaching in Second Language Classrooms. 2007.

[10] P. Miller, "Ten Characteristics of a Good Teacher," English Teach. Forum, vol. 25, no. 1, pp. 36-38, 2012.

[11] A. Budiharso, Teguh \& Arbain, "Immersion Program for Teacher Development Profession," Asian EFL J., vol. 26, no. 6.2, pp. 270-291, 2019.

[12] A. L. Thomas, "Language Teacher Competence and Language Teacher Education," in Language teacher education, R. (The B. C. Bowers, Ed. Modern English Publication, 1987, pp. 33-42.

[13] G. et al Broughton, Teaching English as a Foreign Language, Second. New York: Routledge, 1980.

[14] R. K. Yin, Case Study Research: Design and Method. Thousand Oaks, CA: Sage Publication, 2003.

[15] J. C. Generoso and A. M. M. Arbon, "Language Needs Analysis : An EAP Curriculum Design,” J. Asia TEFL, vol. 17, no. 2, pp. 428-445, 2020.

[16] E. Mede' and Ş. Yalçın, "Utilizing Textbook Adaptation Strategies: Experiences and Challenges of Novice and Experienced EFL Instructors," TESOL Int. J., vol. 14, no. 1, 2019.

[17] T. R. Guskey, Evaluating Professional Development. Thousand Oaks, CA: Corwin Press, 2000.

[18] L. Hibbert and J. W. Foncha, "Improving student's Performance in English as Language of Learning and Teaching in Teacher Pre-service Education," J. English as an Int. Lang., vol. 14, no. 2, pp. 40-54, 2019.

[19] B. Tomlinson, Materials Development in Language Teaching, Second. Cambridge: Cambridge University Press, 2011. 
